\title{
TRACI Assessment of Transportation Manufacturing Nexus in the U.S.: A Supply Chain-linked Cradle-to-Gate LCA
}

\author{
Gokhan Egilmez \\ Department of MCEE, University of New Haven \\ E-mail: gokhanegilmez@gmail.com \\ Yong Shin Park \\ UGPTI, North Dakota State University \\ E-mail: Yong.Park@my.ndsu.edu
}

Received: April 13, 2015 Accepted: April 27, 2015

doi:10.5296/emsd.v4i2.7427ＵRL: http://dx.doi.org/10.5296/emsd.v4i2.7427

\begin{abstract}
Sustainable transportation is an inevitable component of sustainable development intitiatives for mitigating the climate change impacts and stabilizing the rising carbon emissions thus global temperature. In this context, comprehensive analysis of the environmental impact of transportation can play a critical role towards quantifying the midpoint environmental and human health related impacts associated with the transportation activities triggered by manufacturing sectors. This study traces the life cycle impact of the U.S. transportation and manufacturing sectors' nexus using Tool for the Reduction and Assessment of Chemicals and Other Environmental Impacts (TRACI) in the context of the Economic Input-Output Life Cycle Assessment (EIO-LCA) framework considering the following midpoint impact categories: 'global warming', 'particulate matter', 'eutrophication', 'acidification', and 'smog air'. Both direct (onsite) and indirect (supply chain) industries' relationships with transportation industry are considered as the main scope. Results indicated that top ten contributor manufacturing sectors accounted for over 55\% total environmental impacts on each impact category. Additionally, based on the decomposition analysis, food manufacturing sector was found to be the major contributor to smog air with an approximate share of $21 \%$ in the entire supply chain. Automobile related manufacturing sectors also have significant impact on all five life cycle impact categories that the environmental impact of transportation
\end{abstract}


is higher than on-site (direct) impact. Overall decomposition analysis of 53 manufacturing sector indicated that the environmental impact of transportation has severe effects on 'smog air', 'eutrophication' and 'acidification' with a share of $16.4 \%, 10.5 \%$, and $6.0 \%$, respectively. When we consider the average percentage share of transportation related environmental impact on the entire supply chain, U.S manufacturing sectors have a negative impact with a share of $18.8 \%$ of 'smog air', $16.8 \%$ for 'eutrophication', and $8.1 \%$ for 'acidification'.

Keywords: TRACI, EIO-LCA, Life cycle impact assessment, Sustainable transportation /manufacturing nexus

\section{Introduction}

Transportation industry is a critical sector which acts as a bridge between most of the remaining sectors for transporting goods and services in a national economy (Tseng et al., 2005). Especially for manufacturing industries, transportation sector is essential and critical since raw material, semi-finished goods and final products are carried through the industries within the supply chains to the end-users. In spite of its critical contributions to a country's economic sustainability, in fact, transportation industry also acts as a major driver for environmental impacts such as carbon emissions which effects global warming and human health issues significantly (Wakeland et al., 2012), because transportation activities are directy associated with green house gas (GHG) emissions, energy footprints, and dissemination of air pollutants, tbus severely affecting the Earth's sutainability (Huzayyin and Salem, 2013; Costanza and Mageau, 1999). Sustainable transportation is termed as the expression of sustainable development in the transportation sector (Ramani et al., 2009), and significant amount of work has been proposed on quantifying environmental impacts of transportation systems and developing policies towards sustainable transportation systems (Benjaafar and Savelsbergh, 2014). Especially, recent research focuses include invesitation of the interdependencies between economic, environmental and social aspects of transportation systems (Maheshwari et al., 2014). Numerous state of art practical and methodological contributions for the sustainable transporation issues of the U.S. exist in the literature, which include sustainability performance measure of transportation system (Paz et al., 2013), dynamic approach to quantify sustainbility performance of transportaiton systems (Maheshwari et al., 2014, Egilmez and Tatari, 2012), and sustainability footprint modeling for the U.S metropolitan areas (Amekudzi et al., 2009).

Regarding the environmntal impacts of transportation, World Health Organization (WHO, 1999) estimated air pollution generated from motor vehicles, and concluded that air pollution causes more death than all traffic accident. Furthermore, transportation in United States (U.S.) regrettably exacts dreadful toll in damaged health (NSTPRSC, 2007). Although the U.S. accounts for only five percent of world's total population, they contribute over 25 percent of Green House Gases (GHGs), due to rising motor vehicle emissions, fossil fuel consumption, and various industrial activities undertaken in the country's economy (Bell, 2009). According to Environmental Protection Agency's report (EPA, 2013), transportation activities account for $27 \%$ of the national total GHG emissions, while emissions from industrial sectors account for $20 \%$. These statistics reveal that the inherent relationship between the manufacturing 
industries and transportation activities is of importance to study comprehensively from an environmental and socio-economic sustainability perspective (Ewing et al., 2011, Egilmez et al., 2013, 2014). In this context, measuring and evaluating the environmental impact potentials of transportation activities associated with the manufacturing sectors and supply chains of the U.S. economy can be used as a practical approach to address the relationships from a supply chain-linked environmental impact assessment perspective.

While life cycle assessment is generally understood as the quantification of the environmental impacts (e.g. GHG emissions, energy use, water use, etc.) of products or processes, life cycle impact assessment takes the analysis to the next step where human-health (e.g. air pollution) and eco-system related (e.g. eco-toxicity) impacts, so called end-point impacts, are derived from the environmental impacts (Huzayyin and Salem, 2013). Even though, life cycle assessment needs to be performed comprehensively that consideres two dimensions of life cycle assessment: horizontal and vertical. In the horizontal dimensions, multiple environmental impact categories need to be addressed simultaneously, whereas the vertical dimensions need to go through from mid-point to end-point impacts. In fact, majority of the literature on deriving environmental sustainability impacts of transportation activities address the general environmental footprint categories such as carbon, energy and water footprint impacts, where the mid-point impacts are kept out of focus (Egilmez and Park, 2014; Park et al., 2015). In this study, transportation-related impacts of manufacturing activities and supply chains in the U.S. are studied comprehensively with an input-output-based LCA framework where the environmental impacts are traced to the mid-point dimensions such as global warming potential, particulate matter, eutrophication, acidification, smog air. The rest of the paper is organized as follows. Section 2 provides the literature review related to this study. Section 3 describes the economic input-output life cycle assessment (EIO-LCA) methodology. The results and analysis are summarized in Section 4. Finally, Section 5 provides the conclusions and future research.

\section{Literature Review}

Life cycle assessment (LCA) is a well- known and widely used tool to assess the environmental impacts considering the entire life cycle of products or production systems and supply chains, from raw material extraction through acquisition, production, manufacturing, to use and end-of-life and disposal (Hendrickson et al., 1998; Curran, 1996). LCA was firstly used in energy analysis for tracing the environmental burdens in the 1970s and then the full modeling was introduced in the 1980s and improved singnificantly in 1990s. In the last two decades, LCA has been gradually developed as a more comprehensive environment assessment tool (Guinee and Heijungs, 2010) by focusing on various environmental impact categories such as particulate matter, natural environment, resource consumption (renewable and nonrenewable), etc. (Finnveden et al., 2009). In the past decades, international corpoarates around the world started to adopt LCA tools in macro level decision making processes to measure and understand the overall environmental impacts of their processes and products towards realizing their environmental sustainability goals . A typical life cycle inventory (LCI) consists of the amount of all input(s)/output(s) related to the processes that compromises the life cycle of a product or system (Ewing et al., 2011). Among the LCA 
techniques, process-based LCA (P-LCA) and economic input-output LCA (EIO-LCA) are widely used. P-LCA captures the environmental discharges by quantifying energy and material use from all life cycle processes (Ewing et al., 2011). P-LCA has been applied to various research fields such as ready meals (Calderón et al., 2010), fisheries (Vázquez-Rowe et al., 2010; Lozano et al., 2010), agriculture (Mohammadi et al., 2013; Vázquez-Rowe and Villanueva-Rey, 2012), dairy farm (Iribarren et al., 2011; Eide, 2002), energy (Iribarren et al., 2014; Barba-Gutiérrez et al., 2008) and construction (Tatari and Kucukvar, 2011). But these works pay specific attention to the limited phases of the life cycle such as onsite (process impacts) where the indirect impacts associated with supply chains were not considered. Recent literature promotes the use of EIO-LCA developed by Carnegie Mellon University (CMU, 2002), which provide an overview of direct and indirect environmental impact and identify the sectors that contribute most of the manufacturing sector's footprint (Huang et al., 2009). Application of EIO-LCA include estimation of the environmental impact of consumption and household type (Munksgaard et al., 2008), assessment of U.S. food and manufacturing sector's environmental impact (Egilmez et al., 2013), and wastewater for reuse in cooling system associated with tertiary treatment (Theregowda et al., 2014).

The transportation-related life cycle assessment literature is abundant with works which focus on specific phases, such as design or manufacturing process, operation, or end of life, of transportation systems or lack the national economy-wide impacts (Kaniut et al., 1997; Marheineke et al.,1998; Nocker et al., 2000; Facahna and Horvath, 2006; Mayeres et al., 1996; Delucci, 1997; Levinson et al., 1998; Cobal-Flores et al., 1998; Clark, 2003; Schipper, 2004). Only a few publications have provided life cycle impacts of transportation activities comprehensively (considering supply chain impacts) such as freight transportation (Facanha and Horvath, 2006), passenger transportation (Chester and Horvath, 2009; Chester et al., 2010). However, the previous works did not account for mid-point impacts (e.g. global warming, human health, smog air) and most of the time focus was kept limited to tailpipe emissions or conventional environmental impacts. In this study, EIO-LCA is utilized to assess the environmental impacts of transportation activities associated with the U.S. manufacturing sectors from cradle to gate point of view, where Tool for the Reduction and Assessment of Chemicals and other environmental Impacts (TRACI) module is utilized to quantify the mid-point impacts. Several environmental impact indicators are considered, namely: (1) Global warming (2) Acidification (3) Eutrophication (4) particulate matter (5) Smog Air. (For a more detailed discussion about mid-point impacts, see Bare et al. 2000)

\section{Methodology}

\subsection{EIO-LCA Framework}

The Economic Input-Output Life Cycle Assessment (EIO-LCA) is a well-known model that evaluates the environmental impacts of product and process of its entire life cycle. This method utilizes all industry transactions information such as purchasing materials from other industries by one industry, direct and indirect environmental emissions of each industry, in order to estimate the total emission throughout the entire supply chain (CMU, 2002). EIO-LCA was developed by Wassily Leontief in the 1970s based on the nation's economy 


\section{Ml Macrothink}

EIO table with environmental impact multipliers and linear algebra. The mathematical formulation is as shown in Equation 1 (Joshi, 1999) :

$$
X=\left[(I-A)^{-1}\right] f
$$

Where $\boldsymbol{X}$ denotes the total industry output, $\boldsymbol{I}$ refer to the diagonal identity matrix, and $f$ represents the vector of total final demand of industry. In addition, the term $\left[(I-A)^{-1}\right]$ known as Leontief Inverse indicate the total requirement matrix (Leontief, 1986). The total requirement matrix is then multiplied by environmental impact multipliers, termed as $\boldsymbol{E}_{\text {dir }}$. Thus, the total environmental output is expressed as shown in Equation 2 (Hendrickson et al., 2006; Egilmez et al., 2013):

$$
r=E_{d i r} X=E_{d i r}\left[(I-A)^{-1}\right] f
$$

Where $\boldsymbol{r}$ denote the total environmental outputs per unit of final demand, $\boldsymbol{E}_{\text {dir }}$ represents a diagonal matrix which consists of the direct environmental impacts per dollar output of each industrial sector.

\subsection{Data Collection and Assessment}

The aforementioned EIO-LCA framework was utilized for calculating direct plus indirect environmental impacts associated with transportation and manufacturing sector transactions. The scope of this study considers 277 manufacturing sectors and their relationships with the transportation industry. Direct and indirect environmental impact and economic output of entire manufacturing sectors was aggregated into 53 major manufacturing sectors. For example, the food manufacturing sector includes 33 sub sectors such as animal, grain, daily food, etc. and each sub sector has total environmental impact of four major transportation modes (truck, rail, air and water) (Egilmez et al.,2014). Economic input-output data from the U.S. Bureau of Economic Analysis (BEA, 2002) was used to calculate total economic output of transportation activity from each sector.

In this study, TRACI is used in EIO-LCA to collect data. TRACI is a midpoint oriented life cycle assessment tool which includes human and environmental impact category (Theregowda et al., 2014). This study used five environmental impact indicators that are available in EIO-LCA model, including global warming, acidification, eutrophication, particulate matter, and smog air, which are categorized as a midpoint impact in life cycle impact assessment (LCIA). Usually, LCIA translate the findings from the life cycle inventory (LCI) into 12 different environmental impact indicators such as Global warming, Smog formation, Acidification, Eutrophication, Human health cancer, Human health non-cancer, Human health criteria pollutants, Eco-toxicity, Land use, etc. (Bare et al., 2003; Saur, 1997).

\section{Results}

\subsection{Analysis of Life Cycle Impact Inventory}

The life cycle impact inventory of transportation activities betweeen the U.S manufacturing sectors and the final consumers is quantified using the EIO-LCA model. The descriptive 
statistics of life cycle impact inventory for each impact categories are presented in Table 1. The mean of each indicator was founded $3 \mathrm{E}+09 \mathrm{~kg}$ for $\mathrm{GW}, 3 \mathrm{E}+07 \mathrm{~kg}$ for $\mathrm{AC}, 7 \mathrm{E}+06 \mathrm{~kg}$ for $\mathrm{PM}, 1 \mathrm{E}+06 \mathrm{~kg}$ for EU, 8E+08kg for SA and 2811.15 M\$ for economic-output (EO). Moreover, since the interpretation of the LCA is the final phase, the researchers demonstrated the top ten contributors based on the each impact category related to freight transportation activity in Table 2.

Table 1. Descriptive statistics of life cycle impact category

\begin{tabular}{|l|c|c|c|c|c|c|}
\hline Category & GW & AC & PM & EU & SA & EO \\
\hline Mean & $3 \mathrm{E}+09$ & $3 \mathrm{E}+07$ & $7 \mathrm{E}+06$ & $1 \mathrm{E}+06$ & $8 \mathrm{E}+08$ & 2811.15 \\
\hline Standard Error & $6.6 \mathrm{E}+08$ & $7 \mathrm{E}+06$ & $2 \mathrm{E}+06$ & $3 \mathrm{E}+05$ & $2 \mathrm{E}+08$ & 618.484 \\
\hline Median & $1.7 \mathrm{E}+09$ & $2 \mathrm{E}+07$ & $4 \mathrm{E}+06$ & $8 \mathrm{E}+05$ & $4 \mathrm{E}+08$ & 1556.37 \\
\hline Std. Dev. & $4.8 \mathrm{E}+09$ & $5 \mathrm{E}+07$ & $1 \mathrm{E}+07$ & $2 \mathrm{E}+06$ & $1 \mathrm{E}+09$ & 4502.63 \\
\hline Kurtosis & 34.344 & 35.48 & 35.97 & 34.71 & 34.685 & 34.1632 \\
\hline Skewness & 5.41679 & 5.525 & 5.586 & 5.447 & 5.4452 & 5.39823 \\
\hline Range & $3.4 \mathrm{E}+10$ & $3 \mathrm{E}+08$ & $9 \mathrm{E}+07$ & $2 \mathrm{E}+07$ & $1 \mathrm{E}+10$ & 31721.9 \\
\hline Minimum & $1.1 \mathrm{E}+08$ & $1 \mathrm{E}+06$ & $3 \mathrm{E}+05$ & 49505 & $3 \mathrm{E}+07$ & 100.851 \\
\hline Maximum & $3.4 \mathrm{E}+10$ & $3 \mathrm{E}+08$ & $9 \mathrm{E}+07$ & $2 \mathrm{E}+07$ & $1 \mathrm{E}+10$ & 31822.7 \\
\hline Sum & $1.6 \mathrm{E}+11$ & $2 \mathrm{E}+09$ & $4 \mathrm{E}+08$ & $8 \mathrm{E}+07$ & $4 \mathrm{E}+10$ & 148991 \\
\hline Count & 53 & 53 & 53 & 53 & 53 & 53 \\
\hline
\end{tabular}

\subsection{Global Warming}

Global warming $(\mathrm{GW})$ is termed as the average temperature increase of the atmosphere near the surface of earth and in the troposphere, which in turn cause global and regional climate change (Bare et al., 2003; Brentrup et al., 2004). International Panel on Climate Change (IPCC) proposed the most-up-to-date methods for calculating greenhouse gases potency relative to carbon dioxide $\left(\mathrm{CO}_{2}\right)$ (Forster et al., 2007). For instance, "the Earth's average temperature rose about $0.6^{\circ}$ Celsius $\left(1.1^{\circ}\right.$ Fahrenheit) in the 20th century and "a projection of current trends as represented by a number of different scenarios gives temperature increases of about $3^{\circ}$ to $5^{\circ} \mathrm{C}\left(5^{\circ}\right.$ to $9^{\circ}$ Fahrenheit) by the year 2100 or soon afterwards. A $3^{\circ} \mathrm{C}$ or $5^{\circ}$ Fahrenheit rise would likely raise sea levels by about 25 meters (about 82 feet)" (Anon., 2015).

All possible direct and indirect $\mathrm{CO}_{2}$ emissions from freight transportation activities associated with the economic activities among the U.S. manufacturing sectors are considered. From the Table 2, global warming potential are presented in terms of kilograms of $\mathrm{CO}_{2}$ equivalents ( $\mathrm{kg} \mathrm{CO} \mathrm{CO}_{2} \mathrm{eq}$ ) for first top ten manufacturing sector, which has the highest transportation-related GW effect. It can be observed from Table 2 that food manufacturing sector is the dominating sector, which accounted for $21.3 \%$ share of total $\mathrm{Kg} \mathrm{CO}_{2}$-eq of carbon dioxide followed by motor vehicle manufacturing and motor vehicle body, trailer and part manufacturing with $5.8 \%$ and $5.5 \%$ share of total $\mathrm{CO}_{2}$ respectively. The remaining manufacturing sector's potential to global warming ranges between $2.6 \%$ and $4.2 \%$. Transportation of the top ten sectors accounts for $55.8 \%$ of the total global warming potential 
which is over half of the total impact among 53 manufacturing sectors.

\subsection{Particulate Matter}

Particulate matter (PM) is the complex mixture of very small particles that is formulated from anthropogenic processes (e.g. Combustion, resource extraction). Particulate matter is made up of several different sizes such as $\mathrm{PM}_{10}, \mathrm{PM}_{2.5}, \mathrm{PM}_{0.1}$ by emission of nitrate $\left(\mathrm{NO}_{\mathrm{x}}\right)$ and sulphates $\left(\mathrm{SO}_{2}\right)$, organic chemicals, metal, and dust particles, etc. (Bare et al., 2003; Goedkoop and Spriensma, 2000). The PM can be categorized as human health criteria indicator because respiratory tract is a main effect from particle pollution. The PM is measured in $\mu \mathrm{m}\left(\mathrm{PM}_{\mathrm{x}}\right.$ means particles with a size of $\left.\mathrm{X} \mu \mathrm{m}\right)$ and its unit is the kilogram. Total amount of $\mathrm{PM}_{10}$ related to transportation is utilized in this study due to the data availability from EIO-LCA. From the Table 2, similar results are obtained with the GW impact results, $\mathrm{PM}_{10}$ eq emissions are mainly from the food manufacturing sector with a share of $22.6 \%$, followed by motor vehicle manufacturing $(5.8 \%)$ and motor vehicle body, trailer and parts manufacturing (5.4\%). Particulate matter that is related to transportation activity from top ten manufacturing sectors represents about $57.1 \%$ of the total human health impact.

\subsection{Eutrophication}

Eutrophication (EU) is the proliferation of chemical nutrients in an ecosystem which leads to abnormal productivity in an ecosystem (Bare et al., 2003). This causes foul odor, death of fish, reduction of marine mammals. Emission of phosphorous $(\mathrm{P})$, nitrogen $(\mathrm{N})$, and ammonia $\left(\mathrm{NH}_{4}\right)$ from various sources, including cars, truck, and power plants are the key impact to eutrophication within LCIA. Direct and indirect impact of nitrogen is included in the analysis. The unit of eutrophication is the kilogram of $\mathrm{N}$ equivalent $(\mathrm{Kg} \mathrm{N}$-eq). In terms of eutrophication, food manufacturing is still found to be as the dominant sector with $22.1 \%$, which has same portion observed in smog air followed by motor vehicle manufacturing $(5.5 \%)$ and motor vehicle body, trailer, and parts manufacturing (5.3\%). The top ten sector's cumulative percentage is $58.0 \%$ of total eutrophication of transportation activity.

\subsection{Acidification}

The acidification (AC) is the concentration of hydrogen ion $\left[\mathrm{H}^{+}\right]$within a local environment system (Bare et al., 2003). Acid substances travel through three routes (wet, dry, and cloud water deposition). This affects the ecosystem by reducing the alkalinity of lakes or corroding building materials, human-built structure, monuments etc (Norris, 2002). When fossil fuels are burned, they release sulfur dioxide $\left(\mathrm{SO}_{2}\right)$ and nitrogen oxides $\left(\mathrm{NO}_{\mathrm{x}}\right)$ into the atmosphere. It has a fatal impact on the ecosystem change, plant and animal death. The total amount of $\mathrm{SO}_{2}$ associated with transportation activity is obtained from EIO-LCA and it is presented in terms of the kilogram of $\mathrm{SO}_{2}$ equivalents $\left(\mathrm{kg} \mathrm{SO}_{2}\right.$-eq). It is noted that food manufacturing is the dominant sector, which has the highest responsibility on acidification associated with its transportation as shown in Table 2. It accounts for the $22.5 \%$ of total acidification. The second and third sectors that have the highest contribution on acidification are motor vehicle manufacturing and motor body (5.4\%), trailer and parts manufacturing sectors $(5.2 \%)$ 
respectively. The total share of acidification of transportation of the first ten sectors is observed at $58.2 \%$.

\subsection{Smog Air}

Smog Air (SA) refers to ozone $\left(\mathrm{O}_{3}\right)$ which is formed due to the interaction of volatile organic compounds (VOCs) and oxides of nitrogen in the presence of sunlight (Rani et al., 2011). Ozone is located in the upper atmosphere and at the ground level of the earth, which has severe effects on sensitivity vegetation and ecosystems, including forests, wildlife, trees and plants as well as it causes human health effects such as skin cancer, cataracts and serious breathing problem (Bare et al., 2003). Carbone monoxides (CO), sulphur dioxide (SO2), nitrogen oxide (NO) non-methane volatile organic compound (NMVOC) are included in the impact category. This study focused on the total amount of direct plus indirect $\mathrm{O}_{3}$ that is released by transportation from cradle-to-gate manufacturing activity and its measure unit are presented in terms of kilogram of $\mathrm{O}_{3}$ equivalents $\left(\mathrm{kg} \mathrm{O}_{3}\right.$-eq). As shown in Table 2, the results associated with smog air indicate that the food manufacturing sector is the dominant area which has the highest share of smog air in terms of transportation activity. Food manufacturing by itself accounts for $22.1 \%$ of total smog air, which has a huge portion compared to other sectors. The remaining sectors impact range is between $3.0 \%$ and $5.5 \%$, and top ten sectors account for $58.0 \%$ of the total share of smog air.

\subsection{Economic-Output}

Lastly, the economic output of transportation is analyzed for top ten manufacturing sector. According to Table 2, food manufacturing share $21.4 \%$ of total economic output followed by Motor vehicle manufacturing $(5.7 \%)$ and motor vehicle body, trailer, parts manufacturing $(5.5 \%)$ in economic output. Top ten manufacturing sectors are observed to have $56.2 \%$ share of total economic output related to transportation activity.

Table 2. Top Ten Sectors by Percent Shares in Total Transportation Related Impacts

\begin{tabular}{|l|l|l|l|l|l|l|}
\hline Manufacturing Sectors & GW & PM & EU & AC & SA & EO \\
\hline Food manufacturing & 21.3 & 22.6 & 22.1 & 22.5 & 22.1 & 21.4 \\
\hline Motor vehicle manufacturing & 5.8 & 5.8 & 5.5 & 5.4 & 5.5 & 5.7 \\
\hline Motor vehicle body, trailer, and parts manufacturing & 5.5 & 5.4 & 5.3 & 5.2 & 5.3 & 5.5 \\
\hline Nonmetallic mineral product manufacturing & 4.2 & 4.5 & 4.3 & 4.2 & 4.3 & 4.4 \\
\hline Plastics and rubber products manufacturing & 4.2 & 3.8 & 4.4 & 4.3 & 4.4 & 4.2 \\
\hline Basic chemical manufacturing & 3.3 & 3.2 & 3.6 & 3.7 & 3.6 & 3.3 \\
\hline Petroleum and coal products manufacturing & 3.1 & 3.1 & 3.1 & 3.2 & 3.1 & 2.9 \\
\hline Wood product manufacturing & 3.0 & 3.1 & 3.1 & 3.0 & 3.1 & 3.1 \\
\hline Iron and steel mills and manufacturing from purchased steel & 2.9 & 2.9 & 3.6 & 3.6 & 3.6 & 3.0 \\
\hline Converted paper product manufacturing & 2.6 & 2.6 & 3.0 & 2.9 & 3.0 & 2.7 \\
\hline Cumulative Impact & 55.8 & 57.1 & 58.0 & 58.2 & 58.0 & 56.2 \\
\hline
\end{tabular}

\subsection{Supply-Chain Decomposition Analysis}

Results related to decomposition of total impacts by onsite, supply chain and transportation 
are also provided (See Fig. 1 and 2). The onsite impacts refer to the impacts that occurred during the manufacturing/production activites at the site, the transportation impacts refer to the impacts associated with the nexus between transportation and corresponding manufacgturing industries and supply chain impacts refer to the total impact minus (transportation+onsite) impact. It was evident that food manufacturing sector has the highest responsibility of environmental and economic impact from their direct and indirect life cycle perspective from the EIO-LCA results. Other sectors that are included in the top ten also have significant environmental impact associated with its transportation. In order to deal with policy making toward reducing environmental impact of transportation, it is very crucial to look at the proportional environmental impact of transportation from the supply chain perspective. Thus, decomposition analysis for onsite (direct), transportation, and supply chain (indirect) impact was performed as a robust analysis to provide an overall understating of each sector's environmental impact. First, we considered top three manufacturing sector, including food manufacturing, motor vehicle manufacturing, motor vehicle body, and total impact of these three manufacturing sectors for decomposition analysis in Figure 1. The transportation decomposition for 53 sectors by considering supply chain were also analyzed in Figure 2.

Among the five life cycle impact categories, food manufacturing and automobile related manufacturing sectors are more prone to smog followed by eutrophication and they are the predominant impact for top ten sectors. Figure 1 presents how each life cycle impact category's total impact is distributed among the supply chain industries, transportation industu and onsite manufacturing industry. In terms of the food manufacturing sector, the total environmental impact shares for supply chain are ranged between $63 \%$ and $89.7 \%$ for the each impact domain. The environmental impact range of transportation from cradle-to-gate point of view is between $1.8 \%$ and $20.7 \%$. In terms of onsite impact, each environmental impact indicator ranges between $4.9 \%$ and $35.5 \%$. Transportation in the food manufacturing sector shows higher percentage share on smog air accounting $20.7 \%$ of the total. It has a relatively large impact share when compared to the economic output of the transportation activity.

Additionally, eutrophication is a significant impact affected by transportation showing $5.4 \%$ of the total share, which is also higher than the impact of onsite (4.9\%). The impact of transportation on global warming and acidification is still noticeable, and particulate matter has negligible impact. Supply chain sectors are primarily responsible for all impact for the motor vehicle manufacturing sector ranged from $69.4 \%$ to $88.2 \%$ for each impact category. However, transportation has a potential environmental impact on each category in the motor vehicle manufacturing sector, which has a relatively large portion in life cycle impact when compared to its economic activity. The percentage share for each impact category of transportation accounted for a significant amount with $6.1 \%$ of global warming, $11.1 \%$ of acidification, $9.9 \%$ of particulate matter, $21.8 \%$ of eutrophication, and $23.8 \%$ of smog air which also have a dominant impact than the impact from onsite. The environmental impact of motor vehicle body, trailer, and pars manufacturing sector show a similar pattern with the motor vehicle manufacturing sector. Supply chains are observed as the most dominant part 
and the environmental impact of transportation has a greater share of an impact category than onsite as well, which are similar to the previous findings of Egilmez et al. $(2013,2014)$ and Kucukvar et al. (2015).

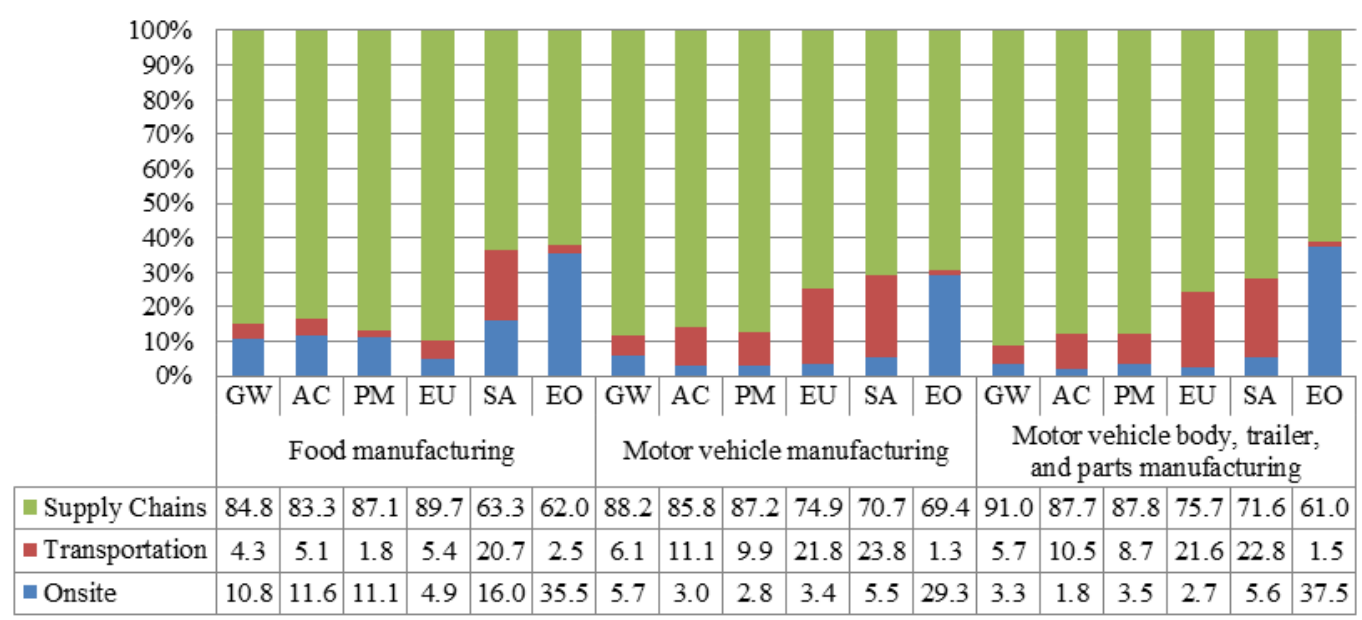

Figure 1. Decomposition analysis result for top three sectors

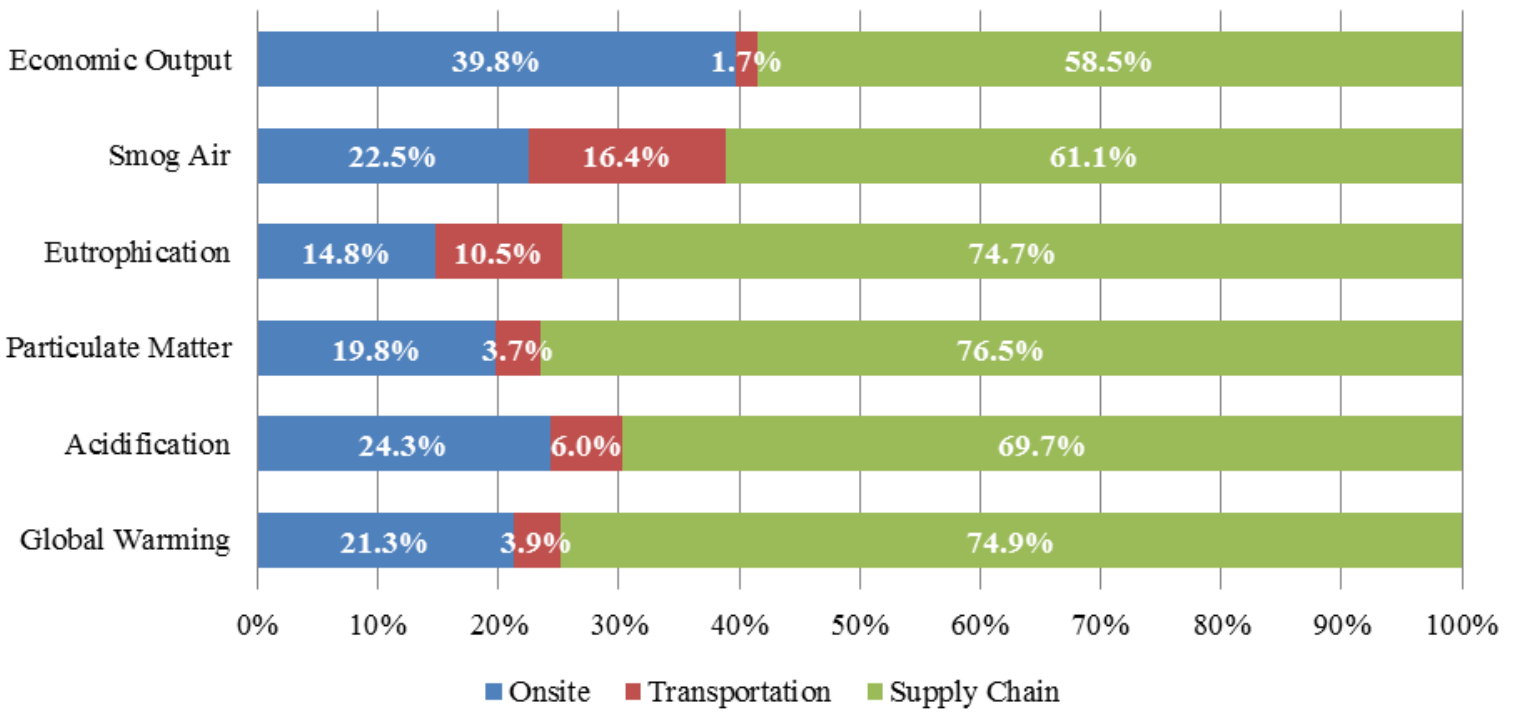

Figure 2. Overall decomposition analysis of the 53 U.S. manufacturing sector's total impacts

From the results of the overall decomposition analysis of the total LCA impact for the 53 manufacturing sectors, the environmental impact of the transportation activities have severe effects on smog air, eutrophication and acidification with a share of $16.4 \%, 10.5 \%$, and $6.0 \%$, respectively. In the last part, the researchers also provided an average percentage share of transportation related impact when the entire supply chain for 53 manufacturing sectors is considered. The analysis shows that the smog air (SA) potential by transportation makes the highest contribution to total environmental impact with an average of $18.8 \%$, followed by eutrophication (EU) with an average of $16.8 \%$. The last but not least, transportation impact on global warming $(\mathrm{GW})$, acidification $(\mathrm{AC})$, and particulate matter $(\mathrm{PM})$ has less than $10 \%$ 


\section{MInstitute Macrothink $_{\text {Int }}^{\text {Intis }}$}

Environmental Management and Sustainable Development

ISSN 2164-7682

2015, Vol. 4, No. 2

of the entire supply chain. It is also shown that the other miscellaneous manufacturing sector is the highest contributor with an average of $17.1 \%$ of five impact categories by transportation relative to supply chain. On the other hand, the basic chemical manufacturing sector has less environmental impact on the average of $3.9 \%$.

Table 3. Average percentage share of transportation-related impacts in supply chain network

\begin{tabular}{|c|c|c|c|c|c|c|c|}
\hline Manufacturing Sector & GW & $\mathrm{AC}$ & PM & EU & SA & Avg. & St. Dev. \\
\hline Aerospace product and parts $\mathrm{mfg}$. & 7.6 & 11.4 & 9.6 & 24.0 & 24.7 & 15.5 & 8.2 \\
\hline Agricultural chemical mfg. & 2.3 & 6.6 & 6.8 & 11.3 & 18.1 & 9.0 & 6.0 \\
\hline Agriculture, construction, and mining machinery mfg. & 5.4 & 10.0 & 8.8 & 20.4 & 21.0 & 13.1 & 7.1 \\
\hline Apparel mfg. & 5.5 & 6.9 & 6.2 & 12.0 & 18.9 & 9.9 & 5.6 \\
\hline Architectural and structural metals mfg. & 4.5 & 11.4 & 9.0 & 23.1 & 23.4 & 14.3 & 8.6 \\
\hline Audio, video, and communications equipment mfg. & 6.4 & 10.0 & 9.5 & 20.6 & 21.7 & 13.7 & 7.0 \\
\hline Basic chemical mfg. & 1.3 & 1.9 & 1.7 & 7.2 & 7.6 & 3.9 & 3.2 \\
\hline Beverage mfg. & 6.3 & 9.1 & 4.0 & 13.5 & 22.1 & 11.0 & 7.1 \\
\hline Boiler, tank, and shipping container mfg. & 4.2 & 9.8 & 8.3 & 22.3 & 20.1 & 12.9 & 7.8 \\
\hline Commercial and service industry machinery mfg. & 5.2 & 5.3 & 5.5 & 15.1 & 15.9 & 9.4 & 5.6 \\
\hline Computer and peripheral equipment $\mathrm{mfg}$. & 6.3 & 9.6 & 9.5 & 19.6 & 20.5 & 13.1 & 6.5 \\
\hline Converted paper product mfg. & 5.2 & 8.0 & 6.2 & 16.6 & 17.0 & 10.6 & 5.8 \\
\hline Cutlerv and handtool mfg. & 4.0 & 8.9 & 7.5 & 20.5 & 21.2 & 12.4 & 7.9 \\
\hline Electric lighting equipment $\mathrm{mfg}$. & 4.6 & 8.3 & 7.6 & 16.7 & 17.0 & 10.9 & 5.7 \\
\hline Electrical equipment mfg. & 4.8 & 9.9 & 8.6 & 22.0 & 22.5 & 13.6 & 8.1 \\
\hline Electronic instrument mfg. & 6.0 & 9.1 & 8.5 & 19.5 & 20.5 & 12.7 & 6.8 \\
\hline Engine, turbine, and power transmission eqpt. mfg. & 5.2 & 9.9 & 8.6 & 20.6 & 21.3 & 13.1 & 7.4 \\
\hline Food mfg. & 4.3 & 5.1 & 1.8 & 5.4 & 20.7 & 7.5 & 7.5 \\
\hline Forging and stamping & 3.9 & 10.3 & 8.4 & 22.1 & 22.6 & 13.5 & 8.5 \\
\hline Foundries & 3.0 & 5.2 & 2.7 & 15.3 & 15.5 & 8.4 & 6.5 \\
\hline Furniture and related product mfg. & 6.5 & 10.4 & 7.3 & 18.3 & 18.9 & 12.3 & 5.9 \\
\hline Household appliance mfg. & 4.7 & 11.1 & 8.9 & 22.7 & 20.9 & 13.6 & 7.8 \\
\hline HVAC and commercial refrigeration equipment mfg. & 5.2 & 10.4 & 8.7 & 22.2 & 22.9 & 13.9 & 8.1 \\
\hline Industrial machinery mfg. & 5.1 & 8.8 & 8.2 & 17.7 & 17.4 & 11.5 & 5.8 \\
\hline Iron and steel mills and mfg. from purchased steel & 2.4 & 10.1 & 7.0 & 20.0 & 20.3 & 12.0 & 8.0 \\
\hline Leather and allied product mfg. & 3.6 & 3.8 & 4.0 & 3.9 & 21.9 & 7.5 & 8.1 \\
\hline Mfg. and reproducing magnetic and optical media & 4.6 & 8.7 & 7.6 & 18.8 & 19.8 & 11.9 & 6.9 \\
\hline Medical equipment and supplies mfg. & 6.4 & 9.0 & 9.0 & 20.9 & 22.6 & 13.6 & 7.6 \\
\hline Metalworking machinery mfg. & 5.1 & 10.4 & 8.6 & 22.4 & 23.1 & 13.9 & 8.3 \\
\hline Motor vehicle body, trailer, and parts mfg. & 5.7 & 10.5 & 8.7 & 21.6 & 22.8 & 13.9 & 7.8 \\
\hline Motor vehicle mfg. & 6.1 & 11.1 & 9.9 & 21.8 & 23.8 & 14.5 & 7.8 \\
\hline Nonferrous metal production and processing & 2.9 & 3.6 & 3.2 & 16.0 & 17.0 & 8.5 & 7.3 \\
\hline Nonmetallic mineral product mfg. & 2.7 & 5.0 & 3.4 & 9.4 & 9.9 & 6.1 & 3.4 \\
\hline Ordnance and accessories mfg. & 4.1 & 7.3 & 6.5 & 17.1 & 17.7 & 10.6 & 6.4 \\
\hline Other chemical product and preparation $\mathrm{mfg}$. & 3.7 & 7.0 & 5.0 & 17.5 & 18.4 & 10.3 & 7.1 \\
\hline Other electrical equipment and component mfg. & 5.1 & 8.1 & 5.8 & 22.3 & 23.5 & 13.0 & 9.1 \\
\hline Other fabricated metal product mfg. & 4.4 & 9.3 & 7.9 & 20.3 & 20.4 & 12.5 & 7.4 \\
\hline Other general purpose machinery mfg. & 5.2 & 9.2 & 8.5 & 19.3 & 19.7 & 12.4 & 6.7 \\
\hline Other miscellaneous mfg. & 8.3 & 12.2 & 11.6 & 25.5 & 27.9 & 17.1 & 9.0 \\
\hline Other transportation equipment $\mathrm{mfg}$. & 5.4 & 9.4 & 8.3 & 19.5 & 19.0 & 12.3 & 6.5 \\
\hline Paint, coating, and adhesive mfg. & 4.7 & 11.1 & 6.7 & 21.3 & 23.2 & 13.4 & 8.4 \\
\hline Petroleum and coal products mfg. & 1.7 & 3.0 & 2.4 & 8.7 & 8.5 & 4.9 & 3.4 \\
\hline Pharmaceutical and medicine mfg. & 4.4 & 8.0 & 7.1 & 13.9 & 15.0 & 9.7 & 4.6 \\
\hline Plastics and rubber products mfg. & 3.3 & 7.0 & 5.3 & 15.5 & 16.4 & 9.5 & 6.0 \\
\hline Printing and related support activities & 5.9 & 7.3 & 6.7 & 15.4 & 15.5 & 10.1 & 4.9 \\
\hline Pulp, paper, and paperboard mills & 2.9 & 4.3 & 2.9 & 9.2 & 10.4 & 6.0 & 3.6 \\
\hline Resin, rubber, and artificial fibers mfg. & 2.2 & 5.1 & 3.4 & 10.1 & 12.0 & 6.6 & 4.3 \\
\hline Semiconductor and other electronic component mfg. & 4.5 & 7.5 & 7.1 & 17.4 & 18.2 & 11.0 & 6.4 \\
\hline Soap, cleaning compound, and toiletry $\mathrm{mfg}$. & 4.0 & 7.6 & 4.8 & 15.2 & 18.1 & 10.0 & 6.4 \\
\hline Textile mills & 3.5 & 4.5 & 2.9 & 7.9 & 12.8 & 6.3 & 4.1 \\
\hline
\end{tabular}




\begin{tabular}{|l|l|l|l|l|l|l|l|}
\hline Textile product mills & 5.0 & 6.4 & 5.0 & 11.5 & 17.4 & 9.1 & 5.4 \\
\hline Tobacco mfg. & 4.3 & 4.6 & 1.8 & 6.8 & 14.3 & 6.4 & 4.8 \\
\hline Wood product mfg. & 6.4 & 7.9 & 3.4 & 10.6 & 13.0 & 8.3 & 3.7 \\
\hline Average & 4.6 & 8.1 & 6.5 & 16.8 & 18.8 & 10.9 & 6.4 \\
\hline
\end{tabular}

\section{Conclusion and Future Work}

In this study, EIO-LCA framework is used to determine the U.S. manufacturing sector's TRACI environmental impacts associated with transportation activities. It was a holistic method to quantify the environmental and human health related impact associated with transportation and manufacturing sector, which also enable an in-depth analysis of all life cycle inventories (LCI) by reducing its complexity. Conducting cradle-to-gate TRACI based environmental impact assessment also provided a comprehensive understanding of the end-point impacts, including global warming, particulate matter, acidification, eutrophication and smog air. The findings of the study revealed that the cumulative environmental impacts of top ten sectors accounted for over $50 \%$ of the total life cycle impacts from raw material extraction to manufacturing/production. The researchers identified that food manufacturing and motor vehicle related manufacturing sectors, predominantly affect the environment. Then, we performed decomposition analysis by looking into onsite (direct), transportation, and supply chain (indirect) impact as a robust method to provide proportional impact by each impact indicator for those hot spot sector. Lastly, the overall decomposition analysis for 53 sector analysis shows that smog (16.4\%), eutrophication $(10.5 \%)$, and acidification $(6.0 \%)$ were the key life cycle impact categories related to transportation activity. It is also noted that smog air (SA) potential by transportation makes the highest contribution to total environmental impact with an average of $18.8 \%$, followed by eutrophication (EU) with an average of $16.8 \%$ when the entire supply chain is considered. It is also noted that smog air (SA) potential by transportation makes the largest contribution to total environmental impact with an average of $18.8 \%$, followed by eutrophication (EU) with an average of $16.8 \%$ when the entire supply chain from cradle-to-gate is considered.

In the U.S, SO2, NOx, and NH3 release were the dominant sources that contribute to smog air and eutrophication, and acidification. Especially, the transportation sector was the most influential source for NOx and VOC emissions accounting for 53\% and 51\% of nation's total emission while $\mathrm{NH}_{3}$ accounted for $4 \%$ (Palmgren, 2004). These pollutants have both direct and indirect effects on human health and eco-system which not only accelerate human diseases, but also have significant impact on agriculture, wildlife, forests, etc. (WHO, 1999). In this regard, transportation policies, including reducing vehicle mile travel (VMT), promoting clean fuels and vehicle efficiency are recommended toward improvement of air quality (Schuster et al., 2004). Ultimately, this study could be a good reference for planners or policy makers for dealing with successful sustainable transportation practices and strategic mitigation with life cycle environmental impact. Current research can be extended towards various directions. First, EIO-LCA did not provide environmental intervention of product use and end-of-life phase (Gokhan Egilmez et al., 2013). Considering use and end-of-life would make the results more comprehensive. In addition, consideration of ecological impacts (Egilmez and Kucukvar, 2014; Kucukvar et al., 2014), land footprint associated with highway network, and inclusion of dynamic simulation models (Egilmez and Tatari, 2011) can be 
critical extensions of current research.

\section{References}

Amekudzi, A. a., Jotin Khisty, C., \& Khayesi, M. (2009). Using the sustainability footprint model to assess development impacts of transportation systems. Transportation Research Part A: Policy and Practice, 43(4), 339-348. http://doi.org/10.1016/j.tra.2008.11.002

Anon. (2015). Definition for global warming - what is global warming? Retrieved June 6, 2015, from http://timeforchange.org/definition-for-global-warming-what-is-global-warming

Barba-Gutiérrez, Y., Adenso-Díaz, B., \& Lozano, S. (2008). Eco-Efficiency of Electric and Electronic Appliances: A Data Envelopment Analysis (DEA). Environ. Model. Assess., 14(4), 439-447.

Bare, J. C., Norris, G. A., \& Pennington, D. W. (2003). The Tool for the Reduction and Assessment of Chemical and Other Environmental Impacts. Industrial Ecology, 6(3), 49-78.

Bare, J.C. et al., (2000). Life Cycle Impact Assessment Workshop Summary Midpoints versus Endpoints: The Sacrifices and Benefits. The International Journal of Life Cycle Assessment, 5(6), 319-326.

BEA. (2002). Bureau of Economic Analysis. Retrieved October 19, 2014, from http://www.bea.gov/industry/io_annual.htm

Bell, J. (2009). Healthy, Equitable Transportation Policy: Recommendations and Research. (S. n Malekafzali, Ed.) (pp. 23-24). Oakland: Prevention Institute.

Benjaafar, S., \& Savelsbergh, M. (2014). Carbon-aware transport and logistics. EURO Journal on Transportation and Logistics, 3(1), 1-3. http://doi.org/10.1007/s13676-014-0049-1

Brentrup, F., Küsters, J., Kuhlmann, H., \& Lammel, J. (2004). Environmental impact assessment of agricultural production systems using the life cycle assessment methodology: I. Theoretical concept of a LCA method tailored to. European Journal of Agronomy, 20(3), 247-264. http://doi.org/10.1016/S1161-0301(03)00039-X

Calderón, L. A., Iglesias, L., Laca, A., Herrero, M., \& Díaz, M. (2010). The utility of Life Cycle Assessment in the ready meal food industry. Resources, Conservation and Recycling, 54(12), 1196-1207. http://doi.org/10.1016/j.resconrec.2010.03.015

Chester, M., \& Horvath, A. (2009). Environmental assessment of passenger transportation should include infrastructure and supply chains. Environmental Research Letters, 4(2), 1-8.

Chester, M., Horvath, A., \& Madanat, S. (2010). Comparison of life-cycle energy and emissions footprints of passenger transportation in metropolitan regions. Atmospheric Environment, 44(8), 1071-1079. http://doi.org/10.1016/j.atmosenv.2009.12.012

Clark, N. N., Gajendran, P., \& Kern, S. M. (2003). A predictive tool for emissions from heavy-duty diesel vehicles. Environmental Science \& Technology, 37(1), 7-15. 
CMU. (2002). EIO-LCA (Economic Input-Output Life Cycle Assessment).

Cobas-Flores, E., Lave, L., Hendrickson, C., McMichael, F., \& Bustani, A. (1998). Motor Vehicles and Passenger Car Bodies Sector: Life Cycle Assessment Using Economic Input Output Analysis. In Society of Automotive Engineers Congress. Detroit, MI.

Costanza, R., \& Mageau, M. (1999). What is a healthy ecosystem ? Aquatic Ecology, 33(1), 105-115. http://doi.org/10.1023/A:1009930313242

Curran, M. (1996). Environmental life-cycle assessment. The International Journal of Life Cycle Assessment, 1(3), 179-179. http://doi.org/10.1007/BF02978949

Delucci, M. (1997). The Annualized Social Cost of Motor Vehicle Use in the U.S. Based on 1990-1991 Data: Summary of Theory, Data, Methods, and Results. In D. L. Greene (Ed.), The Full Costs and Benefits of Transportation - Contributions to Theory, Method and Measurement.

Egilmez, G., \& Kucukvar, M. (2014). Ecological Footprints of U.S. Manufacturing Industry. In IIE Annual Conference \& Expo 2014. Montreal.

Egilmez, G., Kucukvar, M., \& Tatari, O. (2013). Sustainability assessment of U.S. manufacturing sectors: an economic input output-based frontier approach. Journal of Cleaner Production, 53,91-102. http://doi.org/10.1016/j.jclepro.2013.03.037

Egilmez, G., Kucukvar, M., Tatari, O., \& Bhutta, M. K. S. (2014). Supply chain sustainability assessement of the U.S. food manufacturing sectors: A life cycle-based frontier approach. $\begin{array}{llll}\text { Resources, } \quad \text { Conservation } \quad \text { and } & \text { 8-20. }\end{array}$ http://doi.org/10.1016/j.resconrec.2013.10.008

Egilmez,G., \& Park,Y. S. (2014). Transportation Related Carbon, Energy and Water Footprint Analysis of U.S. Manufacturing: A life Cycle-based Sustainability Assessment. Transportation Research Part D: Transport and Environment, 32, 143-159. http://dx.doi.org/10.1016/j.trb.2014.07.001

Egilmez, G., \& Tatari,O. (2012). A Dynamic Modeling Approach to Highway Sustainablity: Strategies to Reduce Overall Impact. Transportation Research, Part A, 46(7), 1086-1096. http://doi.org/10.1016/j.tra.2012.04.011

Eide, M. H. (2002). Life cycle assessment (LCA) of industrial milk production. The International Journal of Life Cycle Assessment, 7(2), 115-126. http://doi.org/10.1007/BF02978855

EPA. (2013). U.S. Greenhouse Gas Inventory Report. Washington: Environmental Protection Agency. Retrieved from http://www.epa.gov/climatechange/ghgemissions/usinventoryreport.html

Ewing, A., Thabrew, L., Perrone, D., Abkowitz, M., \& Hornberger, G. (2011). Insights on the Use of Hybrid Life Cycle Assessment for Environmental Footprinting. Journal of Industrial Ecology, 15(6), 937-950. http://doi.org/10.1111/j.1530-9290.2011.00374.x 
Facanha, C., \& Horvath, A. (2006). Environmental Assessment of Freight Transportation in the U.S. The International Journal of Life Cycle Assessment, 11(4), 229-239. http://doi.org/ 10.1065/lca2006.02.244

Finnveden, G., Hauschild, M., \& Ekvall, T. (2009). Recent developments in life cycle assessment. Journal of Environmental Management, 91(1), 1-21. http://doi.org/10.1016/j.jenvman.2009.06.018.

Forster, P., Ramaswamy, V., Artaxo, P., Berntsen, T., Betts, R., Fahey, D. W., Van Dorland, R. (2007). Changes in Atmospheric Constituents and in Radiative Forcing. In The physical Science Basis (p. Chapter 2). Cambridge, New York: Cambridge University Press.

Goedkoop, M., \& Spriensma, R. (2000). The Eco-indicator 99 A damage oriented method for Life Cycle Impact Assessment: Methodology Report (pp. 35-36). Amersfoort.

Guinee, J., \& Heijungs, R. (2010). Life Cycle Assessment: Past, Present, and Future†. Science \& Technology. Retrieved from http://pubs.acs.org/doi/abs/10.1021/es101316v

Hendrickson, C., Horvath, A., Joshi, S., \& Lave, L. (1998). Economic Input-Output Models for Environmental Life-Cycle Assessment. Environ. Sci. Technol., 32(7), 184A-191A.

Hendrickson, C., Lave, L., \& Matthews, H. (2006). Environmental life cycle assessment of goods and services: An input-output approach (p. 272). Routledge.

Huang, Y., Lezen, M., \& Weber, C. (2009). The role of input-output analysis for the screening of corporate carbon footprints. Economic Systems Research, 21(3), 217-242. http://doi.org/ $10.1080 / 09535310903541348$

Huzayyin, A. S., \& Salem, H. (2013). Analysis of thirty years evolution of urban growth, transport demand and supply, energy consumption, greenhouse and pollutants emissions in Greater Cairo. Research in Transportation Economics, 40(1), 104-115. http://doi.org/10.1016/j.retrec.2012.06.035

Iribarren, D., Hospido, A., Moreira, M. T., \& Feijoo, G. (2011). Benchmarking environmental and operational parameters through eco-efficiency criteria for dairy farms. The Science of the Total Environment, 409(10), 1786-98. http://doi.org/10.1016/j.scitotenv.2011.02.013

Iribarren, D., Vázquez-Rowe, I., Rugani, B., \& Benetto, E. (2014). On the feasibility of using emergy analysis as a source of benchmarking criteria through data envelopment analysis: A case study for wind energy. Energy, 67, 527-537. http://doi.org/10.1016/j.energy.2014.01.109

Joshi, S. (1999). Product Environmental Life - Cycle Assessment Using Input - Output Techniques. Journal of Industrial Ecology, 3(2-3), 95-120.

Kaniut, C., Cetiner, H., \& Franzeck, J. (1997). Life Cycle Assessment of a Complete Car The Mercedes-Benz Approach. In SAE Technical Paper (p. No.971166). http://doi.org/10.4271/971166

Kucukvar, M., Tatari,O., \& Egilmez, G. (2014). Sustainability Assessment of U.S. Final Consumption and Investment: Triple-Bottome-Line Input-Output Analysis. Journal of 
Cleaner Production, 81, 234-243. http://dx.doi.org/10.1016/j.jclepro.2014.06.033

Leontief, W. (1986). Input-output economics. Oxford University Press.

Levinson, D. M., Gillen, D., \& Kanafani, A. (1998). The Social Costs of Intercity Passenger Transportation: A Review and Comparison of Air and Highway. (TRB980274) presented at Transportation Research Board 77th Annual Meeting. In Transportation Research Board 77th Annual Meeting.

Lozano, S., Iribarren, D., Moreira, M. T., \& Feijoo, G. (2010). Environmental impact efficiency in mussel cultivation. Resources, Conservation and Recycling, 54(12), 1269-1277. http://doi.org/10.1016/j.resconrec.2010.04.004

Maheshwari, P., Khaddar, R., Kachroo, P., \& Paz, A. (2014). Dynamic Modeling of Performance Indices for Planning of Sustainable Transportation Systems. Networks and Spatial Economics, 1-23. http://doi.org/10.1007/s11067-014-9238-6

Marheineke, T., Friedrich, R., \& Krewitt, W. (1998). Application of a hybrid-approach to the life cycle inventory analysis of a freight transport task. SAE CONFERENCE Retrieved from http://papers.sae.org/browse/?pg=1739

Mayeres, I., Ochelen, S., \& Proost, S. (1996). The marginal external costs of urban transport. Transportation Research Part D: Transport and Environment, 1(2), 111-130.

Mohammadi, A., Rafiee, S., Jafari, A., Dalgaard, T., Knudsen, M. T., Keyhani, A., ... Hermansen, J. E. (2013). Potential greenhouse gas emission reductions in soybean farming: a combined use of Life Cycle Assessment and Data Envelopment Analysis. Journal of Cleaner Production, 54, 89-100. http://doi.org/10.1016/j.jclepro.2013.05.019

Munksgaard, J., Wier, M., Lenzen, M., \& Dey, C. (2008). Using Input-Output Analysis to Measure the Environmental Pressure of Consumption at Different Spatial Levels. J. Ind. Ecol., 9(1-2), 169-185. http://doi.org/10.1162/1088198054084699

Nocker, L., Panis, L., Torfs, R., \& Extern, E. (2000). A European Accounting Framework for Life Cycle Impact Assessment and External Costs of Transport. In Proceedings of the 2000 Total Life Cycle Conference.

Norris, G. A. (2002). Impact Characterization in the Tool for the Reduction and Assessment of Chemical and Other Environmental Impacts. Journal of Industrial Ecology, 6(3-4), 79-101. http://doi.org/10.1162/108819802766269548

NSTPRSC. (2007). Transportation for Tomorrow (pp. 1-7).

Palmgren, F. (2004). Assessment of the effectiveness of european air quality policies and measures.

Park,Y.S.,Egilmez,G.,\& Kucukvar,M.(2015). A Novel Life Cycle-based Principal Component Analysis Framwork for Eco-efficiency Analysis: Case of the U.S. Manufacturing and Transportation Nexus. Journal of Cleaner Production, 92, 327-342. http://dx.doi.org/10.1016/j.jclepro.2014.12.057 


\section{Macrothink}

Environmental Management and Sustainable Development

ISSN 2164-7682

2015, Vol. 4, No. 2

Paz, A., Maheshwari, P., Kachroo, P., \& Ahmad, S. (2013). Estimation of Performance Indices for the Planning of Sustainable Transportation Systems. Advances in Fuzzy Systems, 2013, 1-13. http://doi.org/10.1155/2013/601468

Ramani, T., Zietsman, J., Eisele, W., \& Rosa, D. (2009). Developing Sustainable Transportation Performance Measures for TxDOT's Strategic Plan: Technical Report, 7(2).

Rani, B., Singh, U., Chuhan, A., Sharma, D., \& Maheshwari, R. (2011). Photochemical Smog Pollution and its mitigation Measures. Journal of Advanced Scientific Research, 2(4), 28-33.

Saur, K. (1997). Special Issue : Current LCA-ISO Activities Life Cycle Impact Assessment. International Journal of Life Cycle Assessment, 2(2), 66-70.

Schipper, Y. (2004). Environmental costs in European aviation. Transport Policy, 11(2), 141-154.

Schuster, T., Schuster, M., Banerjee, A., \& Shankar, A. (2004). Transportation Strategies to Improve Air Quality (pp. 10-12).

Tatari, O., \& Kucukvar, M. (2011). Eco-Efficiency of Construction Materials: Data Envelopment Analysis. Journal of Construction Engineering and Management, 138 (6), 733-741. $\quad$ http://dx.doi.org/10.1061/(ASCE)CO.1943-7862.0000484

Theregowda, R., Vidic, R., Dzombak, D. A., \& Landis, A. E. (2014). Life cycle impact analysis of tertiary treatment alternatives to treat secondary municipal wastewater for reuse in cooling systems. Environmental Progress \& Sustainable Energy. http://doi.org/10.1002/ep.11938

Tseng, Y., Yue, W., \& Taylor, M. (2005). The role of transportation in logistics chain. Eastern Asia Society for Transportation Studies.

Vázquez-Rowe, I., Iribarren, D., Moreira, M. T., \& Feijoo, G. (2010). Combined application of life cycle assessment and data envelopment analysis as a methodological approach for the assessment of fisheries. The International Journal of Life Cycle Assessment, 15(3), 272-283. http://doi.org/10.1007/s11367-010-0154-9

Vázquez-Rowe, I., \& Villanueva-Rey, P. (2012). Joint life cycle assessment and data envelopment analysis of grape production for vinification in the Rías Baixas appellation (NW Spain). Journal of Cleaner Production, 27, 92-102.

Wakeland, W., Cholette, S., \& Venkat, K. (2012). Green Technologies in Food Production and Processing. (J. I. Boye \& Y. Arcand, Eds.) (pp. 211-236). Boston, MA: Springer US. http://doi.org/10.1007/978-1-4614-1587-9

WHO. (1999). Third ministerial conference on environment and health, London. Retrieved July 22, 2014, from http://www.who.dk/london99/transporte.htm 


\section{Macrothink \\ Environmental Management and Sustainable Development \\ ISSN 2164-7682 \\ 2015, Vol. 4, No. 2}

\section{Copyright Disclaimer}

Copyright for this article is retained by the author(s), with first publication rights granted to the journal.

This is an open-access article distributed under the terms and conditions of the Creative Commons Attribution license (http://creativecommons.org/licenses/by/3.0/). 